\title{
Front Matter: Volume 7665
}

, "Front Matter: Volume 7665," Proc. SPIE 7665, Chemical, Biological, Radiological, Nuclear, and Explosives (CBRNE) Sensing XI, 766501 (4 June 2010); doi: 10.1117/12.867301

SPIE Event: SPIE Defense, Security, and Sensing, 2010, Orlando, Florida, United SPIE. States 


\section{PROCEEDINGS OF SPIE}

\section{Chemical, Biological, Radiological, Nuclear, and Explosives (CBRNE) Sensing XI}

Augustus W. Fountain III

Patrick J. Gardner

Editors

6-8 April 2010

Orlando, Florida, United States

Sponsored and Published by

SPIE

Volume 7665 
The papers included in this volume were part of the technical conference cited on the cover and title page. Papers were selected and subject to review by the editors and conference program committee. Some conference presentations may not be available for publication. The papers published in these proceedings reflect the work and thoughts of the authors and are published herein as submitted. The publisher is not responsible for the validity of the information or for any outcomes resulting from reliance thereon.

Please use the following format to cite material from this book:

Author(s), "Title of Paper," in Chemical, Biological, Radiological, Nuclear, and Explosives (CBRNE) Sensing XI, edited by Augustus W. Fountain III, Patrick J. Gardner, Proceedings of SPIE Vol. 7665 (SPIE, Bellingham, WA, 2010) Article CID Number.

ISSN 0277-786X

ISBN 9780819481290

Published by

SPIE

P.O. Box 10, Bellingham, Washington $98227-0010$ USA

Telephone +1 3606763290 (Pacific Time) · Fax +1 3606471445

SPIE.org

Copyright (C) 2010, Society of Photo-Optical Instrumentation Engineers

Copying of material in this book for internal or personal use, or for the internal or personal use of specific clients, beyond the fair use provisions granted by the U.S. Copyright Law is authorized by SPIE subject to payment of copying fees. The Transactional Reporting Service base fee for this volume is $\$ 18.00$ per article (or portion thereof), which should be paid directly to the Copyright Clearance Center (CCC), 222 Rosewood Drive, Danvers, MA 01923. Payment may also be made electronically through CCC Online at copyright.com. Other copying for republication, resale, advertising or promotion, or any form of systematic or multiple reproduction of any material in this book is prohibited except with permission in writing from the publisher. The CCC fee code is 0277-786X/10/\$18.00.

Printed in the United States of America.

Publication of record for individual papers is online in the SPIE Digital Library.

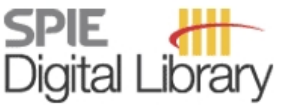

SPIEDigitalLibrary.org

Paper Numbering: Proceedings of SPIE follow an e-First publication model, with papers published first online and then in print and on CD-ROM. Papers are published as they are submitted and meet publication criteria. A unique, consistent, permanent citation identifier (CID) number is assigned to each article at the time of the first publication. Utilization of CIDs allows articles to be fully citable as soon they are published online, and connects the same identifier to all online, print, and electronic versions of the publication. SPIE uses a six-digit CID article numbering system in which:

- The first four digits correspond to the SPIE volume number.

- The last two digits indicate publication order within the volume using a Base 36 numbering system employing both numerals and letters. These two-number sets start with 00, 01, 02, 03, 04 , $05,06,07,08,09,0 A, 0 B \ldots 0 Z$, followed by $10-1 Z, 20-2 Z$, etc.

The CID number appears on each page of the manuscript. The complete citation is used on the first page, and an abbreviated version on subsequent pages. Numbers in the index correspond to the last two digits of the six-digit CID number. 


\section{Contents}

ix Conference Committee

xi Introduction

SESSION 1 INNOVATIONS IN BIODETECTION I

766502 Fate study of water-borne gram positive vegetative bacterial cells with Raman microscopy [7665-01]

J. Guicheteau, U.S. Army Edgewood Chemical Biological Ctr. (United States); A. Tripathi, Science Applications International Corp. (United States); J. Minter, Science and Technology Corp. (United States); P. Wilcox, S. Christesen, U.S. Army Edgewood Chemical Biological Ctr. (United States)

766503 Development of an integrated system for rapid detection of biological agents [7665-02] H. Terazono, Kanagawa Academy of Science and Technology (Japan); H. Takei, Tokyo Medical and Dental Univ. (Japan) and Toyo Univ. (Japan); M. Hayashi, Kanagawa Academy of Science and Technology (Japan); A. Hattori, On-chip Cellomics Consortium Co., Ltd. (Japan); K. Yasuda, Kanagawa Academy of Science and Technology (Japan) and Tokyo Medical and Dental Univ. (Japan)

766504 Estimation and discrimination of aerosols using multiple wavelength LWIR lidar [7665-03] R. E. Warren, EO-Stat, Inc. (United States); R. G. Vanderbeek, U.S. Army Edgewood Chemical Biological Ctr. (United States); J. L. Ahl, JLA Technology Corp. (United States)

766505 Application of the Raven UAV for chemical and biological detection [7665-04] R. Altenbaugh, U.S. Army (United States); J. Barton, C. Chiu, The Johns Hopkins Univ. Applied Physics Lab. (United States); K. Fidler, D. Hiatt, U.S. Unmanned Aircraft Systems (United States); C. Hawthorne, S. Marshall, The Johns Hopkins Univ. Applied Physics Lab. (United States); J. Mohos, AeroVironment, Inc. (United States); V. McHugh, U.S. Army Edgewood Chemical Biological Ctr. (United States); B. Nicoloff, AeroVironment, Inc. (United States)

766506 Backscatter and depolarization measurements of aerosolized biological simulants using a chamber lidar system [7665-05]

D. M. Brown, E. P. Thrush, M. E. Thomas, J. Santarpia, J. Quizon, C. C. Carter, The Johns Hopkins Univ. Applied Physics Lab. (United States)

766507 Optical properties and cross-sections of biological aerosols [7665-06]

E. Thrush, D. M. Brown, N. Salciccioli, J. Gomes, A. Brown, K. Siegrist, M. E. Thomas, N. T. Boggs,

C. C. Carter, The Johns Hopkins Univ. Applied Physics Lab. (United States)

\section{SESSION 2 INNOVATIONS IN BIODETECTION II}

766508 Water matrix and age effects on microorganism Raman microspectroscopy [7665-07] A. Tripathi, R. E. Jabbour, SAIC (United States); P. J. Treado, M. P. Nelson, Chemlmage Corp. (United States); A. P. Snyder, U.S. Army Edgewood Chemical Biological Ctr. (United States) 
766509 Standoff lidar simulation for biological warfare agent detection, tracking, and classification [7665-08]

E. Jönsson, O. Steinvall, O. Gustafsson, F. Kullander, P. Jonsson, Swedish Defence Research Agency (Sweden)

7665 0A Short-range lidar for bioagent detection and classification [7665-09]

N. Hô, F. Émond, F. Babin, INO (Canada); D. Healy, MDA Corp. (Canada); J.-R. Simard,

S. Buteau, J. E. McFee, Defense Research and Development Canada (Canada)

\section{SESSION $3 \quad$ ALGORITHMS FOR CBRNE SENSING}

7665 OD Modeling of spectral emission-based lidar remote sensing [7665-12]

D. V. Plutov, D. K. Killinger, Univ. of South Florida (United States)

$76650 \mathrm{OE}$ A rapidly deployable chemical sensing network for the real-time monitoring of toxic airborne contaminant releases in urban environments [7665-14]

J. J. Lepley, D. R. Lloyd, SELEX Galileo Ltd. (United Kingdom)

7665 OF A framework for evaluating mixture analysis algorithms [7665-15]

S. Dasaratha, T. S. Vignesh, S. Shanmukh, M. Yarra, GE Global Research (India);

E. Botonjic-Sehic, J. Grassi, H. Boudries, I. Freeman, Y. K. Lee, Morpho Detection (United

States); S. Sutherland, Consultant (United States)

$7665 \mathrm{OH}$ Sensor-netting algorithm for CB threat mapping [7665-17]

T. Gruber, L. Grim, MESH, Inc. (United States); C. Keiser, W. Ginley, U.S. Army (United States)

\section{SESSION 4 EXPLOSIVES DETECTION I}

7665 Ol Standoff hyperspectral imaging of explosives residues using broadly tunable external cavity quantum cascade laser illumination [7665-18]

B. E. Bernacki, M. C. Phillips, Pacific Northwest National Lab. (United States)

7665 0J Stoichiometric analysis of ammonium nitrate and ammonium perchlorate with nanosecond laser induced breakdown spectroscopy [7665-19]

S. Sreedhar, S. V. Rao, P. P. Kiran, S. P. Tewari, G. M. Kumar, Univ. of Hyderabad (India)

7665 OL Free surface microfluidic/SERS for detection of gas-phase DNT [7665-21]

B. D. Piorek, S. J. Lee, SpectraFluidics, Inc. (United States); N. Judy, C. D. Meinhart, M. Moskovits, Univ. of California, Santa Barbara (United States); A. Fountain, S. Christesen,

J. Guicheteau, U.S. Army Edgewood Chemical Biological Ctr. (United States)

7665 ON Trace explosive detection in fingerprints with Raman chemical imaging [7665-65]

A. Tripathi, Science Applications International Corp. (United States); E. D. Emmons, National Research Council (United States); J. A. Guicheteau, S. D. Christesen, P. G. Wilcox,

D. K. Emge, A. W. Fountain III, U.S. Army Edgewood Chemical Biological Ctr. (United States)

766500 Trace detection of explosive compounds by different laser-based techniques at the ENEA Laboratories [7665-23]

S. Botti, M. Carpanese, L. Cantarini, G. Giubileo, V. Lazic, ENEA (Italy); S. Jovicevic, Univ. of Belgrade (Serbia); A. Palucci, ENEA (Italy); A. Puiu, Tor Vergata Univ. of Rome (Italy) 
$76650 Q$ Laser vaporization of trace explosives for enhanced non-contact detection [7665-25] R. Furstenberg, M. Papantonakis, C. A. Kendziora, U.S. Naval Research Lab. (United States); D. M. Bubb, U.S. Naval Research Lab. (United States) and Rutgers, The State Univ. of New Jersey (United States); J. Corgan, Rutgers, The State Univ. of New Jersey (United States); R. A. McGill, U.S. Naval Research Lab. (United States)

$7665 \mathrm{OR}$ Intricacies of comparative testing of explosives detectors at the ultra-trace level [7665-26] R. J. Harper, M. E. Fisher, ICx Technologies (United States)

7665 OS High speed spectral measurements of IED detonation fireballs [7665-27]

J. M. Gordon, M. T. Spidell, J. Pitz, K. C. Gross, G. P. Perram, Air Force Institute of Technology (United States)

\section{SESSION 6 EXPLOSIVES DETECTION III}

7665 OT Laser-induced breakdown spectroscopy of RDX and HMX with nanosecond, picosecond, and femtosecond pulses [7665-28]

S. Sreedhar, M. A. Kumar, G. M. Kumar, P. P. Kiran, S. P. Tewari, S. V. Rao, Univ. of Hyderabad (India)

7665 OU Compact standoff Raman system for detection of homemade explosives [7665-29]

A. K. Misra, S. K. Sharma, D. E. Bates, T. E. Acosta, Univ. of Hawai'i (United States)

7665 OV Detection of explosives at trace levels by laser-induced breakdown spectroscopy (LIBS) [7665-30]

V. Lazic, A. Palucci, ENEA (Italy); S. Jovicevic, Univ. of Belgrade (Serbia); M. Carapanese, C. Poggi, ENEA (Italy); E. Buono, ENEA Fellowship (Italy)

7665 OW Xerogel-based molecularly imprinted polymers for explosives detection [7665-31] E. L. Holthoff, D. N. Stratis-Cullum, M. E. Hankus, U.S. Army Research Lab. (United States)

\section{SESSION 7 ADVANCES IN CHEMICAL SENSING I}

7665 OY Extension of a standoff explosive detection system to CBRN threats [7665-33]

A. Ford, R. Waterbury, J. Rose, K. Pohl, Alakai Defense Systems, Inc. (United States); M. Eisterhold, T. Thorn, K. Lee, Lincoln Univ. (United States); E. Dottery, Alakai Defense Systems, Inc. (United States)

$76650 Z$ Laser-induced breakdown plasma-based sensors [7665-34]

S. T. Griffin, The Univ. of Memphis (United States)

766510 Photoacoustic spectroscopy for trace vapor detection and molecular discrimination [7665-35]

E. Holthoff, J. Bender, P. Pellegrino, U.S. Army Research Lab. (United States); A. Fisher, N. Stoffel, Infotonics Technology Ctr. (United States) 
766511 Detection of toxic industrial chemicals in water supplies using surface-enhanced Raman spectroscopy [7665-36]

K. M. Spencer, J. M. Sylvia, S. A. Spencer, S. L. Clauson, ElC Labs., Inc. (United States)

766512 STIRAP on sodium gas as a function of argon buffer gas pressure [7665-37]

J. B. Johnson, S. D. Allen, J. L. Hicks, J. Burdin, Arkansas State Univ. (United States)

766513 CATSI EDM: a new sensor for the real-time passive stand-off detection and identification of chemicals [7665-38]

J.-M. Thériault, Defence Research and Development Canada (Canada); P. Lacasse, AEREX Avionique Inc. (Canada); H. Lavoie, F. Bouffard, Defence Research and Development Canada (Canada); Y. Montembeault, V. Farley, L. Belhumeur, P. Lagueux, Telops, Inc. (Canada)

766514 First field trial results of the MR-CATSI dual input beam spectroradiometer for the standoff detection of chemicals [7665-39]

L. Moreau, ABB Bomem Inc. (Canada); E. Puckrin, C. S. Turcotte, J.-M. Thériault, Defence Research and Development Canada (Canada); C. Vallieres, C. Roy, ABB Bomem Inc. (Canada)

\section{SESSION 8 ADVANCES IN CHEMICAL SENSING II}

766515 FTIR gas analysis with improved sensitivity and selectivity for CWA and TIC detection [7665-40]

C. M. Phillips, H. Tan, MKS Instruments, Inc. (United States)

766516 Airborne infrared-hyperspectral mapping for detection of gaseous and solid targets [7665-41]

E. Puckrin, C. S. Turcotte, P. Lahaie, D. Dubé, Defence Research and Development Canada (Canada); V. Farley, P. Lagueux, F. Marcotte, M. Chamberland, Telops Inc. (Canada)

766517 Imaging open-path Fourier transform infrared spectrometer for 3D cloud profiling [7665-42] J. Rentz Dupuis, D. J. Mansur, R. Vaillancourt, D. Carlson, T. Evans, E. Schundler, OPTRA, Inc. (United States); L. Todd, K. Mottus, The Univ. of North Carolina at Chapel Hill (United States)

766518 Measurement of ammonia skin gas using a mid-infrared Pb-salt tunable diode laser [7665-43]

T. N. Clasp, S. Kaimal, S. W. Reeve, W. A. Burns, Arkansas State Univ. (United States)

766519 A non-negative matrix factorization algorithm for the detection of chemicals from an incomplete Raman library [7665-44]

R. D. Palkki, A. D. Lanterman, Georgia Institute of Technology (United States)

7665 IB Improved Raman sensitivity using polarization analysis [7665-46]

S. Christesen, U.S. Army Edgewood Chemical Biological Ctr. (United States)

7665 1C Proximal detection of chemical warfare agents using PMIRRAS [7665-47]

M. W. P. Petryk, A. J. Marenco, Defence Research and Development Canada (Canada) 
7665 1D Detection of chemicals in mixed, two-dimensional Raman spectra [7665-48]

D. Gillis, J. Grun, J. Bowles, U.S. Naval Research Lab. (United States); R. Lunsford, S. Nikitin,

C. Manka, Research Support Instruments, Inc. (United States)

\section{SESSION 9 RADIOLOGICAL AND NUCLEAR SENSING}

$76651 \mathrm{~A} \quad$ A two-pixel Compton imager [7665-49]

P. R. B. Saull, Institute for National Measurement Standards (Canada); L. E. Sinclair,

H. C. J. Seywerd, Geological Survey of Canada (Canada); P. J. Boyle, A. M. L. MacLeod,

D. S. Hanna, McGill Univ. (Canada)

$7665 \mathrm{IF}$ Thermal neutron detectors based on gadolinium-containing lanthanide-halide nanoscintillators [7665-51]

J. B. Plumley, N. J. Withers, A. C. Rivera, B. A. Akins, J. M. Vargas, Ctr. for High Technology Materials, The Univ. of New Mexico (United States); K. Carpenter, The Univ. of New Mexico (United States); G. A. Smolyakov, Ctr. for High Technology Materials, The Univ. of New Mexico (United States); R. D. Busch, The Univ. of New Mexico (United States); M. Osiński, Ctr. for High Technology Materials, The Univ. of New Mexico (United States)

7665 1G Radiation-induced failures and degradation of wireless real-time dosimeter under highdose-rate irradiation [7665-52]

K. Tsuchiya, K. Kuroki, N. Akiba, K. Kurosawa, National Research Institute of Police Science (Japan); T. Matsumoto, J. Nishiyama, H. Harano, National Institute of Advanced Industrial Science and Technology (Japan)

$766511 \quad$ Radiation scintillator embedded with a converting medium to detect and discriminate the four species of ionizing radiation [7665-54]

S. Pellegrin, C. G. Wilson, Louisiana Tech Univ. (United States)

$76651 \mathrm{~J}$ Design of dual-road transportable portal monitoring system for visible light and gamma-ray imaging [7665-55]

T. P. Karnowski, Oak Ridge National Lab. (United States); M. F. Cunningham, Lawrence Livermore National Lab. (United States); J. S. Goddard, A. M. Cheriyadat, D. E. Hornback,

L. Fabris, R. A. Kerekes, K.-P. Ziock, E. C. Bradley, J. Chesser, Oak Ridge National Lab. (United States); W. Marchant, Univ. of California, Berkeley (United States)

$76651 \mathrm{~L} \quad$ Optical detection of special nuclear materials: an alternative approach for standoff and remote sensing [7665-64]

J. B. Johnson, S. W. Reeve, W. A. Burns, S. D. Allen, Arkansas State Univ. (United States)

7665 1M SmartID: a highly accurate physics-based isotope attribution algorithm [7665-57] M. J. Harrison, G. E. Sjoden, R. Detwiler, Univ. of Florida (United States)

$76651 \mathrm{~N}$ Development of low-power wireless networked radioactive material sensor [7665-61] D. Katsis, Athena Energy Corp. (United States); D. Burns, S. Henriquez, M. Litz, U.S. Army Research Lab. (United States) 
POSTER SESSION

766510 Fluorescence-based optical chemical sensors for personal protection [7665-58]

Š. Korent Urek, A. Lobnik, M. Turel, Univ. of Maribor (Slovenia)

7665 IP Cold plasma decontamination using flexible jet arrays [7665-59]

G. Konesky, K-Plasma, Ltd. (United States)

$76651 Q$ Sensor-enabled chem/bio contamination detection system dedicated to situational awareness of water distribution security status [7665-60]

M. D. Ginsberg, E. D. Smith, V. VanBlaricum, V. F. Hock, U.S. Army Corps of Engineers (United States); D. Kroll, Hach Homeland Security Technologies (United States); K. J. Russell, Electrical Distribution Design (United States)

Author Index 


\title{
Conference Committee
}

\author{
Symposium Chair \\ Michael T. Eismann, Air Force Research Laboratory (United States) \\ Symposium Cochair \\ William Jeffrey, HRL Laboratories, LLC (United States) \\ Conference Chairs
}

Augustus W. Fountain III, U.S. Army Edgewood Chemical Biological Center (United States)

Patrick J. Gardner, Western Carolina University (United States)

\section{Program Committee}

Jerome J. Braun, MIT Lincoln Laboratory (United States)

John C. Carrano, Carrano Consulting (United States)

Christopher C. Carter, The Johns Hopkins University Applied Physics Laboratory (United States)

Harry Ing, Bubble Technology Industries, Inc. (Canada)

Anna Tedeschi, Department of Homeland Security (United States)

Matthew T. Griffin, General Dynamics Armament and Technical Products (United States)

Eric J. Houser, U.S. Department of Homeland Security (United States)

Harold R. McHugh, U.S. Department of Energy (United States)

Paul M. Pellegrino, U.S. Army Research Laboratory (United States)

Michael W. Petryk, Defence Research and Development Canada (Canada)

Cynthia R. Swim, U.S. Army Edgewood Chemical Biological Center (United States)

Steven W. Waugh, Defense Threat Reduction Agency (United States)

Ken Yasuda, U.S. Army Night Vision and Electronic Sensors Directorate (United States)

Session Chairs

1 Innovations in Biodetection I

Steven W. Waugh, Defense Threat Reduction Agency (United States)

2 Innovations in Biodetection II

Steven W. Waugh, Defense Threat Reduction Agency (United States) 
3 Algorithms for CBRNE Sensing

Jerome J. Braun, MIT Lincoln Laboratory (United States)

4 Explosives Detection I

Augustus W. Fountain III, U.S. Army Edgewood Chemical Biological Center (United States)

5 Explosives Detection II

Aaron LaPointe, U.S. Army Night Vision and Electronic Sensors Directorate (United States)

6 Explosives Detection III

Anna Tedeschi, Department of Homeland Security (United States)

$7 \quad$ Advances in Chemical Sensing I

Michael W. Petryk, Defence Research and Development Canada (Canada)

8 Advances in Chemical Sensing II

Paul M. Pellegrino, U.S. Army Research Laboratory (United States)

9 Radiological and Nuclear Sensing

Harry Ing, Bubble Technology Industries, Inc. (Canada) 


\section{Introduction}

This year we held our eleventh annual conference for the Chemical, Biological, Radiological, Nuclear and Explosives (CBRNE) sensing at the SPIE Defense, Security and Sensing (DSS) Symposium in Orlando, Florida U.S.A. The conference continues to grow in strength, both in the number and quality of the technical presentations. The topics being presented at the conference are clearly showing the convergence of multiple CBRNE detection modalities for sensing threats to National Security.

Through the CBRNE Sensing Conference, we continue to see exciting and promising technologies for both point and standoff detection of CBRNE threats. The most exciting advances are in chemical imaging of threats on surfaces. Not only is it capable to identify the specific threat, but now you can correlate it spatially within an image scene. Standoff detection, while still a challenge, continues to show promise. There were several new presentations in multi-photon, laser plasma, non-linear spectroscopic and tunable Quantum Cascade Laser (QCL) approaches. We also saw continued growth in explosives sensing as well in detecting radiological and nuclear threats.

As always, the strength and importance of the SPIE DSS Symposium is that it provides an unprecedented international forum for authors from government, industry, and academia to gather and address a wide variety of sensing issues and technologies. The authors in these conference proceedings represent nearly an equal one-third partition among those groups and are leaders in each of their respective fields.

We want to take this time to particularly thank the members of the program committee for helping us plan, organize, and orchestrate this year's conference. They each work behind scenes all year long to make this conference not only possible, but truly a first rate affair. Whether they come from government laboratories, agencies, industry or academia they bring a tremendous amount of energy and professionalism to help run this conference and make it successful.

We hope that each of you will find value in the proceedings from this year's conference. Augustus W. Fountain III
Patrick J. Gardner 
Downloaded From: https://www.spiedigitallibrary.org/conference-proceedings-of-spie on 26 Apr 2023

Terms of Use: https://www.spiedigitallibrary.org/terms-of-use 